\title{
Chemoenzymatic construction of chiral alkenyl acetylenic alcohol, a key building block to access diastereoisomers of polyacetylenes
}

\author{
Sha-Hua Huang ${ }^{1,2,3^{*}}$, Wenhua Li ${ }^{2}$, Long Chen ${ }^{2}$, Jianhe $\mathrm{Xu}^{3}$ and Ran Hong ${ }^{2 *}$
}

\begin{abstract}
Background: Enzymatic kinetic resolution is proved as an efficient strategy of accessing chiral secondary alcohols in organic synthesis. Although several synthetic methods have been developed for the preparation of chiral acetylenic alcohol, biotransformation remains as a direct approach in the synthesis of polyacetylene lipids, which represent an intriguing class of marine natural products featuring interesting biological profiles.

Results: Novozym 435, a commercial lipase immobilized on macroporous acrylic resin, is utilized in the kinetic resolution of 1-yn-3-ol-4-(E)-ene (alkenyl acetylenic alcohol), which exists as terminus in recently isolated isofulvinol (1) both from the mollusk Peltodoris atromaculata and the sponge Haliclona fulva. The kinetic resolution enabled by Novozym 435 resulted in acetylenic alcohol and the corresponding acetate both in excellent enantiomeric excess and high isolated yield. The optimized reaction conditions allow us to realize the reaction at room temperature in toluene. The reaction is readily scaled up for synthetic use.

Conclusions: The current investigation builds up a platform for future exploration on stereoisomers of isofulvinol, synthetic intermediates with different chain length, and natural product analogs.
\end{abstract}

Keywords: Enzymatic catalysis; Novozym 435; Kinetic resolution; Polyacetylene; Total synthesis

\section{Introduction}

Over 100 polyacetylenes known so far are characterized from the extract of marine sponges of the genera Petrosia, Xestospongia, Strongylophora, etc. [1]. Characteristic of these natural products is a long chain that ranged from $\mathrm{C} 44$ to $\mathrm{C} 47$ that are bearing acetylenic, hydroxyl or keto, and isolated cis/trans-alkenes. Most polyacetylenic lipids have shown promising biological activities, such as antitumor, antimicrobial, and antiviral $[2,3]$. Very recently, Ciavatta and coworkers isolated several long-carbon-chain (C46) and fulvinol-like polyacetylenes from the ether extract of both the mollusk Peltodoris atromaculata and the sponge Haliclona fulva [4]. Among them, two compounds, isofulvinol (1) and hydroxydehydroisofulvinol (2)

\footnotetext{
* Correspondence: shahua@sit.edu.cn; rhong@sioc.ac.cn

'School of Chemical and Environmental Engineering, Shanghai Institute of Technology, Shanghai 201418, China

${ }^{2}$ CAS Key Laboratory of Synthetic Chemistry of Natural Substances, Shanghai Institute of Organic Chemistry, CAS, 345 Lingling Road, Shanghai 200032, China

Full list of author information is available at the end of the article
}

(Figure 1), showed in vitro promising growth inhibitory activity against a panel of six human cancer cell lines with the $\mathrm{IC}_{50}$ values that ranged from 3 to $36 \mu \mathrm{M}$. It may also be essential for understanding some basic biological phenomena, including chemical defense mechanisms since $H$. fulva was reported as the nudibranch feeds for the mollusk $P$. atromaculata [5].

The rare resources of marine sponges as well as diverse biological profiles attract several total syntheses of selected targets [6-11]. These syntheses focused on the construction of acetylenic alcohols in a highly enantioselective manner through hydroboration, catalytic asymmetric hydrogenation, as well as enzymatic resolution. The direct acetylene addition of enal with chiral alkynylzinc complex was documented to be highly substrate dependent $[8,12,13]$. The enzymatic kinetic resolution in literature precedents revealed the power of achieving high enantioselectivity of the recovered acetylenic alcohols as well as the esterication product [7-11,14]. Lipase AK, Lipase PS, and Novozym 435 were proved as efficient biocatalysts for this type of substrates. However, 
<smiles>C#CC(O)C=CCCCCCCCCC=CC=CCCCCC/C=C/C(O)C#C</smiles>

isofulvinol (1)

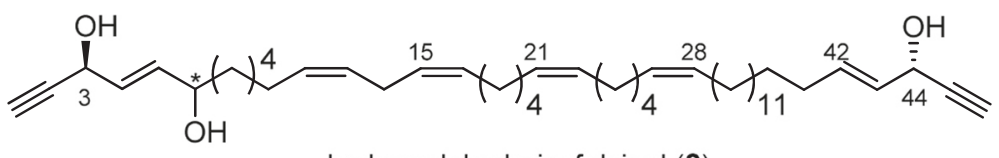

hydroxydehydroisofulvinol (2)

Figure 1 Isofulvinol (1) and hydroxydehydroisofulvinol (2).

target-oriented synthesis (TOS) is limited to a specific target instead of developing a general approach to diversify structural features of polyacetylenes. Only two recent reports undertook this task and disclosed interesting biological profiles $[13,14]$. However, the chain length and levels of desaturation (numbers and geometry) as well as the chirality for adjusting biological activity remain elusive. Guided under this line, we initiated a synthetic effort to devise a unified and practical strategy for the future evaluation of the structure-and-activity relationship in terms of carbon chain length and chirality of acetylenic alcohols.

With the consideration of isolated cis-alkenes, the long carbon chain, and two identical chiral 1-yn-3-ol-4-(E)-ene terminuses, isofulvinol (4) is denoted as a good starting point to develop a general approach which may eventually guide us to synthesize its stereoisomers with different chain length using a flexible synthetic tactics. Retrosynthetically, cis-alkenyl bisaldehyde $\mathbf{5}$ can be derived from partial hydrogenation (Lindlar catalyst) of symmetric internal alkyne 6 and stepwise Wittig olefination (Scheme 1). In order to collect both enantiomers of two 1-yn-3-ol-4- $(E)$ ene units $\mathbf{3}$ and $\mathbf{4}$, an enzymatic kinetic resolution is envisioned to be an ideal option since both isomers are expected to achieve in high enantiomeric excess (e.e.). Moreover, this flexible tactics may offer an opportunity to establish the unknown chiral center in hydroxydehydroisofulvinol (2) (Figure 1) via introducing a hydroxyl group at $\mathrm{C} 6$ in $\mathbf{3}$ or its derivative.

\section{Results and discussion}

The synthesis of acetylenic alcohol $\mathrm{rac}-\mathbf{3}$ was begun from the commercially available brominated alcohol 7 (Scheme 2). After standard Swern oxidation [15] and Wittig chain elongation, the corresponding ester 9 was further reduced by diisobutylaluminum hydride (DIBAL-H) and subsequent $\mathrm{MnO}_{2}$ oxidation [16] to deliver enal 10, which smoothly reacted with an acetylenic Grignard reagent to give acetylenic alcohol 3 in an impressively overall $76 \%$ yield for five straightforward steps. The corresponding

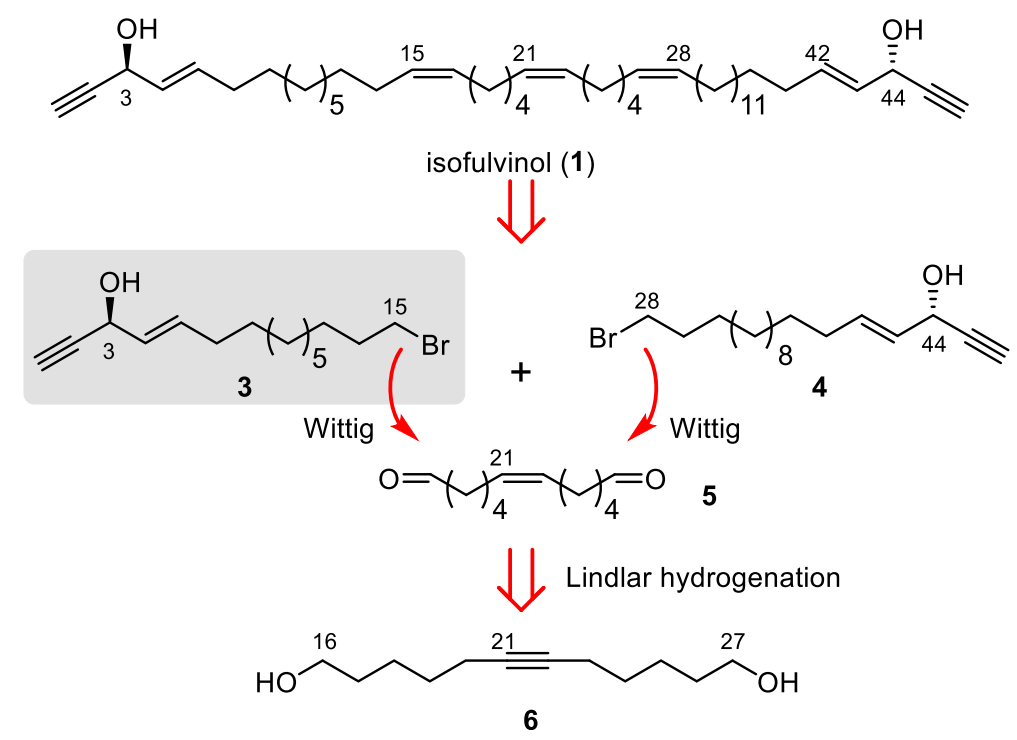

Scheme 1 Synthesis design of isofulvinol (1) (chiral moiety 3 was highlighted as the focus of the current research). 


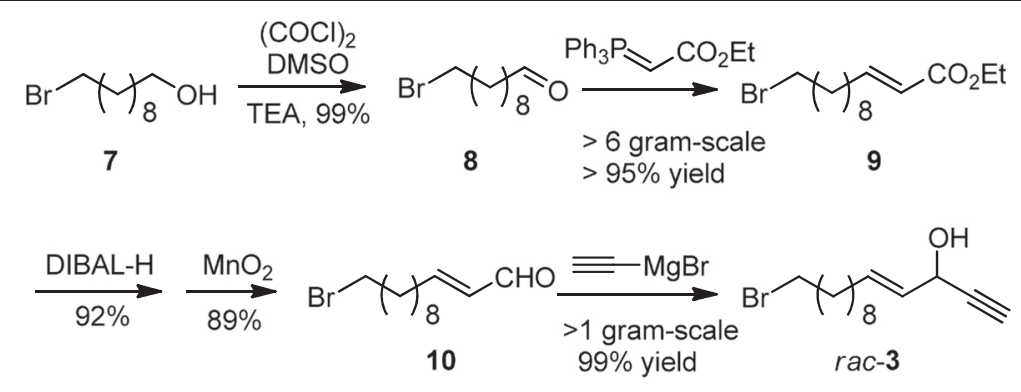

Scheme 2 Gram-scale synthesis of racemic acetylenic alcohol 3.

substance was readily cumulated in a gram scale. Three literature-known biocatalysts were screened, and only Novozym 435 gave a controllable conversion in $97 \%$ e.e. of the recovered alcohol (entry 2 in Table 1). For Lipase AK, the recovered alcohol was confirmed without a considerable enantiomeric excess during the reaction process (entry 1). Lipase PS gave a sluggish reaction and low selectivity $(E=7)$ (entry 3$)$.

We then focused on solvent screening with the combination of Novozym 435. As shown in Table 2, enzymatic kinetic resolution was performed with a slow rate in polar solvents (entries 1 to 4). The activity of enzyme is correlated with the hydrophobicity of the solvent $(\log P$, $P$ is the partition coefficient between 1-octanol and water) [17] (entries 1 to 9). In hexane and octane, however, the reaction was rather fast and not easy to maintain the alcohol $\mathbf{3}$ and the corresponding acetate $\mathbf{1 1}$ both in high enantioselectivities ( $E=17$ in entry 10 vs $E=340$ in entry 8). Toluene was identified as the solvent of choice both for the reaction time and enantioselectivity (entry 7 vs 14 ). The resolution efficiency $(E)$ for a synthetically useful scale $(>200 \mathrm{mg}$ ) remains excellent (entry 15). The dramatic deterioration of activity in n-hexane during the increase of conversion ${ }^{\mathrm{a}}$ may be due to the conformational adjustment of biocatalyst [17] (entry 10 vs 8). Although the $E$ number remains excellent when the reaction was performed in octane (entry 11 vs 9), overesterification was found when the reaction was scaled up. The absolute configuration of the recovered chiral acetylenic alcohol 3 was determined to be $R$ by the modified Mosher ester [18] (Additional file 1). Since the corresponding ester $(S)$-11 was not able to achieve a baseline separation on chiral HPLC columns, hydrolysis with $\mathrm{K}_{2} \mathrm{CO}_{3}$ in $\mathrm{MeOH}$ was performed and $(S)-3$ was obtained in good yield (Scheme 3). The corresponding acetylic alcohol was assigned as $S$ by the comparison with the HPLC profile of the recovered $(R)-3$. Its enantiomeric excess is also impressively high as $97 \%$. That means all diastereoisomers of isofulvinol (1) can be accessed in excellent enantiomeric purity by utilizing Novozym 435. Enzymatic resolution provided one pair of enantiomers in high e.e. which is suitable for further synthetic usage and derivatization ${ }^{\mathrm{b}}[19]$.

\section{Conclusion}

In summary, we devised an efficient protocol to access both enantiomers of the chiral acetylenic alcohol motif in high enantiomeric excess (both $>97 \%$ e.e.). The synthesis design discussed in this work would allow us to access a series of isofulvinol stereoisomers and derivatives through the mutation of chain length and the alternation of the stereochemistry of secondary alcohols,

Table 1 Identification of biocatalyst for the resolution of rac-3

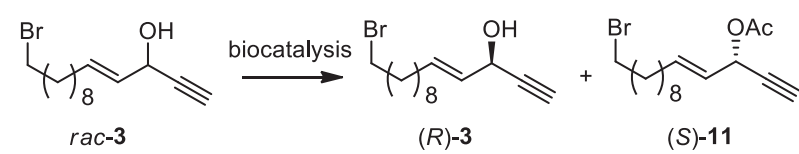

\begin{tabular}{|c|c|c|c|c|c|c|}
\hline \multirow{2}{*}{ Entry } & \multirow{2}{*}{ Biocatalyst } & \multirow{2}{*}{ Time (h) } & \multirow{2}{*}{ Conversion (\%) ${ }^{\mathrm{a}}$} & $(R)-3^{b}$ & $(S)-11^{b}$ & \multirow{2}{*}{$E^{c}$} \\
\hline & & & & \% e.e. & $\%$ e.e. & \\
\hline 1 & Lipase AK & 0.5 & $>99$ & 0 & 0 & - \\
\hline 2 & Novozym 435 & 0.5 & 56 & 96 & 97 & 340 \\
\hline 3 & Lipase PS & 27.5 & 76 & 98 & 32 & 7 \\
\hline
\end{tabular}

Reaction conditions: rac-3 $(151 \mathrm{mg}, 0.5 \mathrm{mmol})$, biocatalyst $(250 \mathrm{mg}, 165 \% \mathrm{w} / \mathrm{w})$, vinyl acetate $(307 \mu \mathrm{L}, 6.6 \mathrm{mequiv}), \mathrm{n}$-hexane $(5 \mathrm{~mL}), \mathrm{R} . \mathrm{T}$. ${ }^{\mathrm{a} C o n v e r s i o n ~ w a s ~ d e t e r m i n e d ~}$ by HPLC (Chiralcel AS-H; flow rate: $0.50 \mathrm{~mL} / \mathrm{min}$; ${ }^{i} \mathrm{PrOH} / \mathrm{n}$-hexane: $1 / 99$; temperature: $\left.25^{\circ} \mathrm{C} ; \mathrm{UV}: \lambda=199 \mathrm{~nm}\right)$; ${ }^{b}$ the determination of enantiomeric excess (HPLC chiralcel AS-H) and the absolute configuration (Mosher ester) of 3 are illustrated in Additional file $1 ;{ }^{c} E=\ln [(1-$ e.e.s $)(1-C)] / \ln [(1+$ e.e.s $)(1-C)]$, where e.e.s represents the enantiomeric excess of the recovered alcohol. 
Table 2 Solvent effect on the optimization of enzymatic kinetic resolution of acetylenic alcohol 3

\begin{tabular}{|c|c|c|c|c|c|c|c|}
\hline \multirow[t]{2}{*}{ Entry } & \multirow[t]{2}{*}{ Solvent } & \multirow[t]{2}{*}{$\log P$} & \multirow[t]{2}{*}{$t(\mathrm{~h})$} & \multirow[t]{2}{*}{ Conversion (\%) } & \multirow{2}{*}{$\begin{array}{l}(R)-3^{b} \\
\% \text { e.e. }\end{array}$} & \multirow{2}{*}{$\begin{array}{l}\text { (S)-11 } \\
\% \text { e.e. }\end{array}$} & \multirow[t]{2}{*}{$E^{c}$} \\
\hline & & & & & & & \\
\hline 1 & Dioxane & -1.10 & 1.5 & 4 & 2.2 & 58.0 & 4 \\
\hline 2 & $\mathrm{CH}_{3} \mathrm{CN}$ & -0.33 & 1.5 & 22 & 23.3 & 95.2 & 51 \\
\hline 3 & Acetone & -0.23 & 1.5 & 15 & 20.6 & $80^{e}$ & 11 \\
\hline 4 & $\mathrm{THF}$ & 0.49 & 1.5 & 13 & 10.0 & 84.5 & 13 \\
\hline 5 & $\mathrm{Et}_{2} \mathrm{O}$ & 0.85 & 1.5 & 46.6 & 78.7 & 95.0 & 94 \\
\hline 6 & ${ }^{t} \mathrm{BuOMe}$ & 0.96 & 1.5 & 45 & 76.4 & 97.0 & 152 \\
\hline 7 & Toluene & 2.50 & 1.5 & 49.3 & 91.1 & 96.6 & 185 \\
\hline 8 & n-Hexane & 3.50 & 0.5 & 56 & 96.0 & 97.7 & 340 \\
\hline 9 & n-Octane & 4.50 & 0.5 & 51.1 & 89.0 & 97.9 & 284 \\
\hline 10 & n-Hexane & 3.50 & 6 & 60.0 & 96.0 & 64.2 & 17 \\
\hline 11 & n-Octane & 4.50 & 6 & 54.3 & 98.4 & 96.2 & 300 \\
\hline 12 & $\mathrm{Et}_{2} \mathrm{O}$ & 0.85 & 6 & 52.9 & 97.7 & 89.2 & 78 \\
\hline 13 & ${ }^{\mathrm{t}} \mathrm{BuOMe}$ & 0.96 & 6 & 52.4 & 98.4 & 91.6 & 109 \\
\hline 14 & Toluene & 2.50 & 6 & 50.3 & 98.4 & 97.3 & 354 \\
\hline $15^{\mathrm{d}}$ & Toluene & 2.50 & 6 & 50.3 & 97.4 & 97.3 & 319 \\
\hline
\end{tabular}

Reaction conditions: rac-3 (30 mg, $0.1 \mathrm{mmol})$, Novozym 435 (20 mg, 67\% w/w, 1,000 U/mmol), vinyl acetate (62 $\mu \mathrm{L}, 6.6$ equiv), solvent (1 mL), R.T. ${ }^{\mathrm{a} C o n v e r s i o n ~(C) ~}$ was determined by HPLC (Chiralcel AS-H; flow rate: $0.50 \mathrm{~mL} / \mathrm{min}$; ${ }^{\mathrm{P}} \mathrm{PrOH} / \mathrm{n}$-hexane: $1 / 99$; temperature: $25^{\circ} \mathrm{C} ; \mathrm{UV}: \lambda=199 \mathrm{~nm}$ ); ${ }^{b}$ the determination of enantioselectivity (HPLC Chiralcel AS-H) and the absolute configuration (Mosher's method) of 3 are illustrated in Additional file 1 ; ${ }^{c} E=\ln [(1-$ e.e.s) $(1-C)] / \ln [(1+$ e.e.s) $(1-C)]$, where e.e.s represents the enantiomeric excess of the recovered alcohol; ${ }^{d} 257 \mathrm{mg}$ of rac-3 was applied, see the Experimental section for details; ${ }^{\mathrm{e}}$ since considerable side products were contaminated, the HPLC determination ( $80 \%$ e.e.) of $(R)-3$ was not calibrated.

which may further provide a comprehensive investigation of biological evaluation. Current investigation of total synthesis of the target molecule as well as its derivatization is underway in this laboratory and will be reported in due course.

\section{Experimental section}

\section{General procedure}

All the reactions were carried out under $\mathrm{N}_{2}$ atmosphere unless otherwise stated. Solvents utilized for reactions were dried using the standard procedure and distilled before use. All reagents were used after receiving albeit special treatment as indicated.

${ }^{1} \mathrm{H}$ NMR and ${ }^{13} \mathrm{C}$ NMR were recorded on Bruker AM-400 (Bruker AXS, Inc., Madison, WI, USA) and Agilent NMR-vnmrs 400 (Agilent Technologies, Inc., Santa Clara, CA, USA) spectrometers in $\mathrm{CDCl}_{3} .{ }^{1} \mathrm{H}$ NMR data were recorded as follows: multiplicity $(\mathrm{s}=$ singlet, $\mathrm{d}=$ doublet, $\mathrm{t}=$ triplet, $\mathrm{m}=$ multiplet or unresolved, coupling constant in $\mathrm{Hz}$, integration). IR spectra $\left(\mathrm{cm}^{-1}\right)$ were

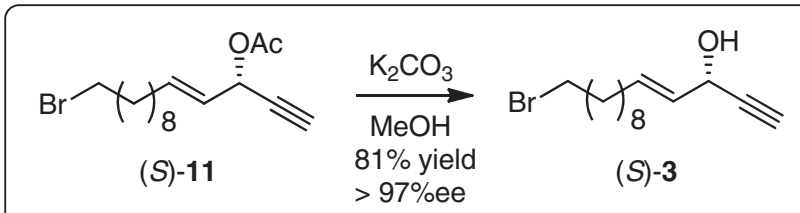

Scheme 3 Preparation of (S)-3 from hydrolysis of (S)-11. recorded on a PerkinElmer 983 Digital FT-IR spectrometer (PerkinElmer, Waltham, MA, USA) or Bruker Tensor 27 (Bruker AXS, Inc., Madison, WI, USA). Mass spectra were determined on a Shimadzu LCMS-2010EV (ESI) mass spectrometer (Shimadzu Corporation, Kyoto, Japan) or Agilent G6100 LC/MSD (ESI) single Quand mass spectrometer (Agilent Technologies, Inc., Santa Clara, CA, USA). High-resolution mass spectra were recorded on Bruker Daltonics, Inc. APEXIII 7.0 TESLA FTMS (ESI) mass spectrometers (Bruker Daltonics, Inc., Billerica, MA, USA). Optical rotation was taken on JASCO P1030 (JASCO Analytical Instruments, Easton, MD, USA). Enantiomeric excess was determined by DIONEX UltiMate 3000 chiral HPLC (Thermo Fisher Scientific, Inc., Waltham, MA, USA). Lipase from Candida antarctica (5,000 U/g) was used (Novozym 435, Sigma-Aldrich, Saint Louis, USA). The melting point was not calibrated.

Preparation of (E)-15-bromopentadec-4-en-1-yn-3-ol (rac-3) 11-Bromoundecanal (8): A solution of $\mathrm{CH}_{2} \mathrm{Cl}_{2}(25 \mathrm{~mL})$ and oxalyl chloride $(1.0 \mathrm{~mL}, 11 \mathrm{mmol})$ was added a solution of DMSO $(1.7 \mathrm{~mL}, 22 \mathrm{mmol})$ in dry $\mathrm{CH}_{2} \mathrm{Cl}_{2}(5 \mathrm{~mL})$ at $-60^{\circ} \mathrm{C}$. The corresponding mixture was stirred for $15 \mathrm{~min}$, and then a solution of 11-bromo-1-undecanol (7) $(2.512 \mathrm{~g}, 10 \mathrm{mmol})$ in $\mathrm{CH}_{2} \mathrm{Cl}_{2}(10 \mathrm{~mL})$ was added dropwise over $5 \mathrm{~min}$. After being stirred for $15 \mathrm{~min}$, $\mathrm{Et}_{3} \mathrm{~N}(7.0 \mathrm{~mL}, 50 \mathrm{mmol})$ was added and then the 
reaction mixture was gradually warmed up to room temperature. The reaction was quenched with water $(50 \mathrm{~mL})$, and the aqueous layer was extracted with $\mathrm{CH}_{2} \mathrm{Cl}_{2}(2 \times 25 \mathrm{~mL})$. The combined organic layers were washed with $\mathrm{HCl}$ (aq., $1 \% v / v)$ and brine $(3 \times 40 \mathrm{~mL}$ ) and then dried over anhydrous $\mathrm{Na}_{2} \mathrm{SO}_{4}$. After the removal of the organic solvent, the residue was subjected to purification by flash column chromatography ( $\mathrm{PE} / \mathrm{EA}=$ $50 / 1)$ to give 8 as colorless oil $(2.473 \mathrm{~g}, 99 \%$ yield). ${ }^{1} \mathrm{H}$ NMR $\left(400 \mathrm{MHz}, \mathrm{CDCl}_{3}\right): \delta 9.76(\mathrm{t}, J=1.4 \mathrm{~Hz}, 1 \mathrm{H})$, $3.41(\mathrm{t}, J=6.8 \mathrm{~Hz}, 2 \mathrm{H}), 2.42(\mathrm{td}, J=7.3,1.6 \mathrm{~Hz}, 2 \mathrm{H}), 1.81$ to $1.89(\mathrm{~m}, 2 \mathrm{H}), 1.59$ to $1.65(\mathrm{~m}, 2 \mathrm{H}), 1.38$ to 1.44 (m, $2 \mathrm{H}), 1.27$ to $1.34(\mathrm{~m}, 10 \mathrm{H})$.

(E)-ethyl 13-bromotridec-2-enoate (9): A solution of 11-bromoundecanal (8) $(6.2 \mathrm{~g}, 25 \mathrm{mmol})$ and $\mathrm{Ph}_{3} \mathrm{P}=$ CHCOOEt $(9.135 \mathrm{~g}, 26.25 \mathrm{mmol})$ in toluene $(125 \mathrm{~mL})$ was refluxed about $3 \mathrm{~h}$ until the aldehyde was completely consumed. The reaction mixture was cooled to room temperature and diluted with petroleum ether $(250 \mathrm{~mL})$. A white precipitate was removed through a pad of Celite (Shanghai Dahe Chemicals, Inc., Shanghai, China) and thoroughly washed with petroleum ether. The combined filtrate was concentrated under reduced pressure, and the residue was subjected to purification by flash column chromatography (PE/EA $=50 / 1)$ to afford 9 as yellow oil (7.15 g, 89\% yield). ${ }^{1} \mathrm{H}$ NMR (400 MHz, $\left.\mathrm{CDCl}_{3}\right): \delta 6.96(\mathrm{dt}, J=15.6,7.0 \mathrm{~Hz}, 1 \mathrm{H}), 5.81(\mathrm{dt}, J=15.6$, $1.4 \mathrm{~Hz}, 1 \mathrm{H}), 4.18(\mathrm{q}, J=7.1 \mathrm{~Hz}, 2 \mathrm{H}), 3.41(\mathrm{t}, J=6.9 \mathrm{~Hz}$, $2 \mathrm{H}), 2.16$ to $2.22(\mathrm{~m}, 2 \mathrm{H}), 1.81$ to $1.89(\mathrm{~m}, 2 \mathrm{H}), 1.38$ to $1.47(\mathrm{~m}, 4 \mathrm{H}), 1.26$ to $1.33(\mathrm{~m}, 13 \mathrm{H})$; LRMS-ESI: calcd. for $\mathrm{C}_{15} \mathrm{H}_{27} \mathrm{BrNaO}_{2}[\mathrm{M}+\mathrm{Na}]^{+}$: 341.1, found: 341.0.

$(E)$-13-bromotridec-2-enal (10): A solution of $(E)$-ethyl 13-bromotridec-2-enoate (9) (1.877 g, $5.88 \mathrm{mmol})$ in toluene $(30 \mathrm{~mL})$ was stirred at $0^{\circ} \mathrm{C}$ for $10 \mathrm{~min}$. Then DIBAL-H (10.3 mL, 1.2 M in toluene) was added dropwise within $15 \mathrm{~min}$, and the resulting mixture was stirred for additional $30 \mathrm{~min}$. The reaction was quenched by $\mathrm{H}_{2} \mathrm{O}(0.65 \mathrm{~mL})$, and the resulting reaction mixture formed into gel; vigorous stirring was needed before the gel ages into a precipitate. The suspension was filtered by Celite ${ }^{\bullet}$ and washed with ethyl acetate. The filtrate was concentrated under reduced pressure, and the corresponding residue was subjected to purification by flash column chromatography $(\mathrm{PE} / \mathrm{EA}=10 / 1)$ to deliver (E)-13-bromotridec-2-en-1-ol as colorless oil (1.505 g, 92\% yield). ${ }^{1} \mathrm{H}$ NMR (400 MHz, $\mathrm{CDCl}_{3}$ ): $\delta 5.59$ to 5.73 $(\mathrm{m}, 2 \mathrm{H}), 4.08(\mathrm{~m}, 2 \mathrm{H}), 3.41(\mathrm{t}, J=6.9 \mathrm{~Hz}, 2 \mathrm{H}), 2.03$ (q, $J=7.2 \mathrm{~Hz}, 2 \mathrm{H}), 1.81$ to $1.89(\mathrm{~m}, 2 \mathrm{H}), 1.33$ to 1.44 (m, $4 \mathrm{H}), 1.25$ to $1.32(\mathrm{~m}, 10 \mathrm{H}) ;{ }^{13} \mathrm{C}$ NMR $(100 \mathrm{MHz}$, $\left.\mathrm{CDCl}_{3}\right): \delta 133.36,128.81,63.68,34.01,32.79,32.17$, 29.43, 29.40, 29.38, 29.12, 29.09, 28.72, 28.13; FT-IR: $v\left(\mathrm{~cm}^{-1}\right) 3,334(\mathrm{br}), 2,925,2,853,1,464,1,438,1,254$, 1,089, 1,002, 969, 722, 645, 562; HRMS-ESI: calcd. for $\mathrm{C}_{13} \mathrm{H}_{25} \mathrm{BrNaO}[\mathrm{M}+\mathrm{Na}]^{+}$: 299.0986, found: 299.0981 .
A suspension of above (E)-13-bromotridec-2-en-1-ol $(1.45 \mathrm{~g}, 5.23 \mathrm{mmol})$ and $\mathrm{MnO}_{2}(4.47 \mathrm{~g}, 52.3 \mathrm{mmol})$ in $\mathrm{CH}_{2} \mathrm{Cl}_{2}(20 \mathrm{~mL})$ was stirred at room temperature. The reaction process was monitored by TLC. After completion, the mixture was filtered by Celite ${ }^{\circ}$ and washed with $\mathrm{CH}_{2} \mathrm{Cl}_{2}$. The filtrate was concentrated under reduced pressure, and the residue was subjected to purification by flash column chromatography $(\mathrm{PE} / \mathrm{EA}=50 / 1)$ to give 10 as yellow oil (1.277 g, $89 \%$ yield). ${ }^{1} \mathrm{H}$ NMR $\left(400 \mathrm{MHz}, \mathrm{CDCl}_{3}\right): \delta 9.51(\mathrm{~d}, J=7.9 \mathrm{~Hz}, 1 \mathrm{H}), 6.85(\mathrm{dt}$, $J=15.6,6.8 \mathrm{~Hz}, 1 \mathrm{H}), 6.12(\mathrm{dd}, J=15.8 \mathrm{~Hz}, J=7.8 \mathrm{~Hz}$, $1 \mathrm{H}), 3.41(\mathrm{t}, J=6.8 \mathrm{~Hz}, 2 \mathrm{H}), 2.34(\mathrm{q}, J=6.8 \mathrm{~Hz}, 2 \mathrm{H}), 1.81$ to $1.89(\mathrm{~m}, 2 \mathrm{H}), 1.47$ to $1.54(\mathrm{~m}, 2 \mathrm{H}), 1.39$ to 1.44 $(\mathrm{m}, 2 \mathrm{H}), 1.27$ to $1.36(\mathrm{~m}, 10 \mathrm{H}) ;{ }^{13} \mathrm{C}$ NMR $(100 \mathrm{MHz}$, $\left.\mathrm{CDCl}_{3}\right): \delta 194.06,158.98,132.90,33.98,32.76,32.67$, 29.31, 29.24, 29.06, 28.67, 28.09, 27.77; FT-IR: $v\left(\mathrm{~cm}^{-1}\right)$ 2,927, 2,854, 2,731, 1,692, 1,637, 1,460, 1,438, 1,256, 1,153, 1,009, 974, 722, 644, 561; HRMS-ESI: calcd. for $\mathrm{C}_{13} \mathrm{H}_{23} \mathrm{BrNaO}[\mathrm{M}+\mathrm{Na}]^{+}:$297.0830, found: 297.0824 .

(E)-15-bromopentadec-4-en-1-yn-3-ol ( $r a c-3):$ A solution of (E)-13-bromotridec-2-enal (10) (1.164 g, $4.23 \mathrm{mmol})$ in tetrahydrofuran (THF) $(30 \mathrm{~mL})$ was stirred at $0^{\circ} \mathrm{C}$ for $10 \mathrm{~min}$. Then ethynylmagnesium bromide $(12.7 \mathrm{~mL}, 0.5 \mathrm{M}$ in THF) was added dropwise, and the resulting reaction mixture was stirred for $3 \mathrm{~h}$. The reaction was diluted with ether $\left(50 \mathrm{~mL}\right.$ ) and quenched by addition of $\mathrm{NH}_{4} \mathrm{Cl}$ (aq., $5 \mathrm{~mL}$ ). The organic layer was separated, and the aqueous layer was extracted with $\mathrm{Et}_{2} \mathrm{O}(2 \times 15 \mathrm{~mL})$. The combined organic layers were washed successively by $\mathrm{NaHCO}_{3}$ (aq.), water, and brine and dried over $\mathrm{Na}_{2} \mathrm{SO}_{4}$. After removal of the solvent, the residue was subjected to purification by flash column chromatography $(\mathrm{PE} / \mathrm{EA}=10 / 1)$ to deliver the corresponding alcohol ( $\mathrm{rac}-3)$ as radial crystal $(1.3 \mathrm{~g}$, $99 \%$ yield). mp: $27^{\circ} \mathrm{C}$ to $28^{\circ} \mathrm{C}$; ${ }^{1} \mathrm{H}$ NMR (400 MHz, $\left.\mathrm{CDCl}_{3}\right): \delta 5.92(\mathrm{dt}, J=15.2,7.0 \mathrm{~Hz}, 1 \mathrm{H}), 5.60(\mathrm{dd}, J=15.2$, 6.4 Hz, $1 \mathrm{H}), 4.84(\mathrm{t}, J=5.6 \mathrm{~Hz}, 1 \mathrm{H}), 3.41(\mathrm{t}, J=6.9 \mathrm{~Hz}$, $2 \mathrm{H}), 2.56(\mathrm{~d}, J=2.2 \mathrm{~Hz}, 1 \mathrm{H}), 2.06(\mathrm{q}, J=7.6 \mathrm{~Hz}, 2 \mathrm{H}), 1.88$ (d, $J=6.0 \mathrm{~Hz}, 1 \mathrm{H}), 1.81$ to $1.89(\mathrm{~m}, 2 \mathrm{H}), 1.36$ to 1.46 (m, 4H), 1.26 to $1.33(\mathrm{~m}, 10 \mathrm{H}) ;{ }^{13} \mathrm{C}$ NMR $(100 \mathrm{MHz}$, $\left.\mathrm{CDCl}_{3}\right): \delta 134.36,128.38,83.40,73.87,62.65,34.02,32.79$, $31.89,29.40,29.36,29.11,28.78,28.71,28.12$; FT-IR: $v\left(\mathrm{~cm}^{-1}\right) 3371(\mathrm{br}), 3,305,2,926,2,854,1,459,1,438$, $1,255,1,089,1,012,968,721,647,561$; HRMS-ESI: calcd. for $\mathrm{C}_{15} \mathrm{H}_{25} \mathrm{BrNaO}[\mathrm{M}+\mathrm{Na}]^{+}$: 323.0986, found: 323.0981 .

\section{Enzymatic resolution of (E)-15-bromopentadec-4-en-1-yn-3-ol (rac-3)}

$(R)$-15-bromopentadec-4-en-1-yn-3-ol $((R)-3)$ and $(S)$-15bromopentadec-4-en-1-yn-3-yl acetate ((S)-11): A suspension of alcohol (rac-3) $(257 \mathrm{mg}, 0.853 \mathrm{mmol})$, Novozym 435 (172 mg, 5,000 U/g, recombinant, expressed in Aspergillus niger) and vinyl acetate $(524 \mu \mathrm{L}, 8.53 \mathrm{mmol})$ in toluene $(8.5 \mathrm{~mL})$ was stirred at room temperature. The 
reaction process was monitored by chiral HPLC. After completion $(6 \mathrm{~h})$, the mixture was filtered by Celite ${ }^{\circ}$. The filtrate was concentrated under reduced pressure, and the residue was subjected to purification by flash column chromatography (PE/EA $=50 / 1$ to $10 / 1$ ) to give $(R)-3$ (125 mg, 48\% yield) and $(S)$-11 (150 mg, 51\% yield).

$(R)-3:[\alpha]_{\mathrm{D}}^{25}=-20.8\left(\mathrm{c} 1.00, \mathrm{CHCl}_{3}\right) ; 97.4 \%$ e.e., HPLC (Chiralcel AS-H; flow rate: $0.50 \mathrm{~mL} / \mathrm{min}$; ${ }^{\mathrm{i} r O H} / \mathrm{n}$-hexane: 1/99; temperature: $25^{\circ} \mathrm{C}$; UV: $\lambda=199 \mathrm{~nm}$ ); $\mathrm{mp}: 31^{\circ} \mathrm{C}$ to $32^{\circ} \mathrm{C} ;{ }^{1} \mathrm{H}$ NMR $\left(400 \mathrm{MHz}, \mathrm{CDCl}_{3}\right): \delta 5.92(\mathrm{dt}, J=15.2$, $7.0 \mathrm{~Hz}, 1 \mathrm{H}), 5.60(\mathrm{dd}, J=15.2,6.4 \mathrm{~Hz}, 1 \mathrm{H}), 4.84$ $(\mathrm{t}, J=5.6 \mathrm{~Hz}, 1 \mathrm{H}), 3.41(\mathrm{t}, J=6.9 \mathrm{~Hz}, 2 \mathrm{H}), 2.56(\mathrm{~d}$, $J=2.2 \mathrm{~Hz}, 1 \mathrm{H}), 2.06(\mathrm{q}, J=7.6 \mathrm{~Hz}, 2 \mathrm{H}), 1.88(\mathrm{~d}, J=6.0 \mathrm{~Hz}$, $1 \mathrm{H}), 1.81$ to $1.89(\mathrm{~m}, 2 \mathrm{H}), 1.36$ to $1.46(\mathrm{~m}, 4 \mathrm{H}), 1.26$ to $1.33(\mathrm{~m}, 10 \mathrm{H}) ;{ }^{13} \mathrm{C}$ NMR $\left(100 \mathrm{MHz}, \mathrm{CDCl}_{3}\right): \delta 134.36$, $128.38,83.40,73.87,62.65,34.02,32.79,31.89,29.40$, 29.36, 29.11, 28.78, 28.71, 28.12; FT-IR: $v\left(\mathrm{~cm}^{-1}\right)$ 3,371 (br), 3,305, 2,926, 2,854, 1,459, 1,438, 1,255, 1,089, 1,012, 968, 721, 647, 561.

(S)-11: $[\alpha]_{\mathrm{D}}^{25}=+22.3$ (c $\left.1.00, \mathrm{CHCl}_{3}\right) ; 96.5 \%$ e.e., HPLC (Chiralcel AS-H; flow rate: $0.50 \mathrm{~mL} / \mathrm{min}$; ${ }^{\mathrm{i}} \mathrm{PrOH} / \mathrm{n}$-hexane: 1/99; temperature: $25^{\circ} \mathrm{C}$; UV: $\left.\lambda=199 \mathrm{~nm}\right) ;{ }^{1} \mathrm{H}$ NMR $\left(400 \mathrm{MHz}, \mathrm{CDCl}_{3}\right): \delta 6.02(\mathrm{dtd}, J=15.4,6.8,0.8 \mathrm{~Hz}, 1 \mathrm{H})$, $5.83(\mathrm{~d}, J=5.6 \mathrm{~Hz}, 1 \mathrm{H}), 5.54(\mathrm{ddt}, J=15.2,6.8,1.4 \mathrm{~Hz}$, $1 \mathrm{H}), 3.41(\mathrm{t}, J=6.8 \mathrm{~Hz}, 2 \mathrm{H}), 2.56(\mathrm{~d}, J=2.2 \mathrm{~Hz}, 1 \mathrm{H}), 2.09$ (s, 3H), 2.06 (m, 2H, overlap), 1.81 to $1.89(\mathrm{~m}, 2 \mathrm{H}), 1.36$ to $1.44(\mathrm{~m}, 4 \mathrm{H}), 1.25$ to $1.32(\mathrm{~m}, 10 \mathrm{H}) ;{ }^{13} \mathrm{C}$ NMR $(100 \mathrm{MHz}$, $\left.\mathrm{CDCl}_{3}\right): \delta 169.67,137.15,124.24,79.85,74.67,64.05$, $34.01,32.79,31.94,29.39,29.36,29.33,29.08,28.72,28.58$, 28.13, 21.06; FT-IR: $v\left(\mathrm{~cm}^{-1}\right) 3,296,2,927,2,854,1,743$, $1,458,1,437,1,370,1,228,1,015,968,642$; HRMS-ESI: calcd. for $\mathrm{C}_{17} \mathrm{H}_{27} \mathrm{BrNaO}_{2}[\mathrm{M}+\mathrm{Na}]^{+}$: 365.1092, found: 365.1087.

\section{Hydrolysis of acetate to prepare (S)-15-bromopentadec-4-en- 1-yn-3-ol ((S)-3)}

A suspension of $(S)-\mathbf{1 1}(68.5 \mathrm{mg}, 0.2 \mathrm{mmol})$ and anhydrous $\mathrm{K}_{2} \mathrm{CO}_{3}(276 \mathrm{mg}, 2 \mathrm{mmol})$ in $\mathrm{CH}_{3} \mathrm{OH}(1 \mathrm{~mL})$ was stirred at room temperature. The reaction process was monitored by TLC. After completion, the mixture was diluted by $\mathrm{Et}_{2} \mathrm{O}$. The organic layer was washed successively by water and brine and dried over $\mathrm{Na}_{2} \mathrm{SO}_{4}$. After removal of the organic solvent, the residue was subjected to purification by flash column chromatography $(\mathrm{PE} / \mathrm{EA}=10 / 1)$ to deliver the corresponding alcohol $(S)-3$ as radial crystal (48 mg, $81 \%$ yield). $[\alpha]_{\mathrm{D}}^{25}=+24.0$ (c $1.00, \mathrm{CHCl}_{3}$ ); $97.3 \%$ e.e., HPLC (Chiralcel AS-H; flow rate: $0.50 \mathrm{~mL} / \mathrm{min}$; ${ }^{i} \mathrm{PrOH} / \mathrm{n}$-hexane: $1 / 99$; temperature: $25^{\circ} \mathrm{C}$; UV: $\lambda=199 \mathrm{~nm}$ ); mp: $27^{\circ} \mathrm{C}$ to $28^{\circ} \mathrm{C} ;{ }^{1} \mathrm{H}$ NMR (400 MHz, $\left.\mathrm{CDCl}_{3}\right): \delta 5.92(\mathrm{dt}$, $J=15.2,7.0 \mathrm{~Hz}, 1 \mathrm{H}), 5.60(\mathrm{dd}, J=15.2,6.4 \mathrm{~Hz}, 1 \mathrm{H}), 4.84$ $(\mathrm{t}, J=5.6 \mathrm{~Hz}, 1 \mathrm{H}), 3.41(\mathrm{t}, J=6.9 \mathrm{~Hz}, 2 \mathrm{H}), 2.56(\mathrm{~d}$, $J=2.2 \mathrm{~Hz}, 1 \mathrm{H}), 2.06(\mathrm{q}, J=7.6 \mathrm{~Hz}, 2 \mathrm{H}), 1.88(\mathrm{~d}, J=6.0 \mathrm{~Hz}$, $1 \mathrm{H}), 1.81$ to $1.89(\mathrm{~m}, 2 \mathrm{H}), 1.36$ to $1.46(\mathrm{~m}, 4 \mathrm{H}), 1.26$ to $1.33(\mathrm{~m}, 10 \mathrm{H}) ;{ }^{13} \mathrm{C}$ NMR $\left(100 \mathrm{MHz}, \mathrm{CDCl}_{3}\right): \delta 134.36$,
$128.38,83.40,73.87,62.65,34.02,32.79,31.89,29.40$, 29.36, 29.11, 28.78, 28.71, 28.12; FT-IR: $v\left(\mathrm{~cm}^{-1}\right) 3,371$ (br), 3,305, 2,926, 2,854, 1,459, 1,438, 1,255, 1,089, 1,012, 968, 721, 647, 561 .

\section{Endnotes}

${ }^{a}$ The conversions in Tables 1 and 2 were directly taken from the HPLC integration. This number should be adjusted since there are different absorption of alcohol (3) and the resulting acetate (11). This system error will not affect the qualitative comparison of enzymatic efficiency in different organic solvents.

${ }^{\mathrm{b}} \mathrm{A}$ recent elegant dynamic kinetic resolution of 1-yn-3-ol4-ene utilizing Novozym 435 with acid resin as a racemization reagent was reported by $\mathrm{Xu}$ and coworkers (see [19]).

\section{Additional file}

Additional file 1: Supporting information available. The detailed information of the Mosher method for the absolute configuration identification of (R)-3, ${ }^{1} \mathrm{H}$ and ${ }^{13} \mathrm{C}$ NMR spectra of all unknown compounds, and HPLC profiles for compounds $\mathbf{3}$ and $\mathbf{1 1}$ are available free of charge via the Internet or directly from the authors.

\section{Competing interests}

The authors declare that they have no competing interests.

\section{Authors' contributions}

$\mathrm{SHH}$ and $\mathrm{RH}$ conceived the project and designed the strategy of synthesis. WL and LC performed the experiments. SHH, JX and RH wrote the manuscript. All authors discussed results and proofread the manuscript.

\section{Acknowledgements}

Financial supports from the National Natural Science Foundation of China (No. 21402121 to S.-H. Huang) and The MOST (2011CB710800 to R. Hong) are highly appreciated. SH Huang also thanks the financial support by the Open Funding Project of the State Key Laboratory of Bioreactor Engineering at ECUST.

\section{Author details}

${ }^{1}$ School of Chemical and Environmental Engineering, Shanghai Institute of Technology, Shanghai 201418, China. ${ }^{2}$ CAS Key Laboratory of Synthetic Chemistry of Natural Substances, Shanghai Institute of Organic Chemistry, CAS, 345 Lingling Road, Shanghai 200032, China. 'State Key Laboratory of Bioreactor Engineering, East China University of Science and Technology, 130 Meilong Road, Shanghai 200237, China.

Received: 9 September 2014 Accepted: 26 December 2014 Published online: 04 March 2015

\section{References}

1. Dembitsky VM (2006) Anticancer activity of natural and synthetic acetylenic lipids. Lipids 41:883-924

2. Siddiq A, Dembitsky V (2008) Acetylenic anticancer agents. Anti-Cancer Agents Med Chem 8:132-170

3. Minto RE, Blacklock BJ (2008) Biosynthesis and function of polyacetylenes and allied natural products. Prog Lipid Res 47:233-306

4. Ciavatta ML, Nuzzo G, Takada K, Mathieu V, Kiss R, Villani G, Gavagnin M (2014) Sequestered fulvinol-related polyacetylenes in Peltodoris atromaculata. J Nat Prod 77:1678-1684

5. Gemballa S, Schermutzki F (2004) Cytotoxic haplosclerid sponges preferred: a field study on the diet of the dotted sea slug Peltodoris atromaculata (Doridoidea: Nudibranchia). Mar Biol 144:1213-1222

6. Morishita K, Kamezawa M, Ohtani T, Tachibana H, Kawase M, Kishimoto M, Naoshima Y (1999) Chemoenzymatic synthesis of (1)-docosa-4,15-dien-1-yn-3-ol, 
a component of the marine sponge Cribrochalina vasculum, and confirmation of the structure and absolute configuration of the acetylenic alcohol, by lipase-catalysed biotransformations. J Chem Soc, Perkin Trans 1:513-518

7. Gung BW, Dickson H, Shockley S (2001) A concise synthesis of (+)- and (-)-adociacetylene B. Tetrahedron Lett 42:4761-4763

8. Gung BW, Dickson HD, Seggerson S, Bluhm K (2002) A short synthesis of an acetylenic alcohols from the sponge cribrochalina vasculum. Synth Commun 32:2733-2740

9. Gung BW, Omollo AO (2008) First total synthesis of the potent anticancer natural product dideoxypetrosynol A: preparation of the "skipped"

(Z)-enediyne moiety by oxidative coupling of homopropargylphosphonium ylide. Eur J Org Chem 4790-4795

10. Gung BW, Omollo AO (2008) Total synthesis of (+)- and (-)-duryne: a potent anticancer agent from the marine sponge Cribrochalina dura. Establishment of the central double bond geometry and the absolute configuration of the chiral centers. J Org Chem 73:1067-1070

11. Mori K, Akasaka K, Matsunaga S (2014) Chemoenzymatic synthesis and HPLC analysis of the stereoisomers of miyakosyne A [(4E,24E)-14-methyloctacosa-4,24diene-1,27-diyne-3,26-diol], a cytotoxic metabolite of a marine sponge Petrosia sp., to determine the absolute configuration of its major component as 3R,14R,26R. Tetrahedron 70:392-401

12. Kirkham JED, Courtney TDL, Lee V, Baldwin JE (2005) Asymmetric synthesis of cytotoxic sponge metabolites R-strongylodiols $A$ and $B$ and an analogue. Tetrahedron 61:7219-7232

13. El Arfaoui El, Listunov D, Fabing I, Oukessou M, Frongia C, Lobjois V, Samson A, Ausseil F, Ben-Tama A, El Hadrami El H, Chauvin R, Génisson Y (2013) Identification of chiral alkenyl- and alkynylcarbinols as pharmacophores for potent cytotoxicity. ChemMedChem 8:1779-1786

14. Shirouzu T, Watari T, Ono M, Koizumi K, Saiki I, Tanaka C, Rob WM, Soest V, Miyamoto T (2013) Structure, synthesis, and biological activity of a C-20 bisacetylenic alcohol from a marine sponge Callyspongia sp. J Nat Prod 76:1337-1342

15. Mancuso AJ, Huang SL, Swern D (1978) Oxidation of long-chain and related alcohols to carbonyls by dimethyl sulfoxide "activated" by oxalyl chloride. J Org Chem 43:2480-2482

16. Paquette LA, Heidelbaugh TM (1996) (4S)-(-)-tert-Butyldimethylsiloxy-2cyclopen-1-one. Org Synth 73:44-47

17. Carrea G, Ottolina G, Riva S (1995) Role of solvents in the control of enzyme selectivity in organic media. Trends Biotech 13:6-70

18. Dale JA, Mosher HS (1973) Nuclear magnetic resonance enantiomer reagents. Configurational correlations via nuclear magnetic resonance chemical shifts of diastereomeric mandelate, O-methylmandelate, and $a$-methoxy- $a$-trifluoromethylphenylacetate (MTPA) esters. J Am Chem Soc 95:512-519

19. Wu JP, Meng X, Wang L, Xu G, Yang LR (2014) Highly efficient dynamic kinetic resolution of secondary aromatic alcohols at low temperature using a low-cost sulfonated sepiolite as racemization catalyst. Tetrahedron Lett 55:5129-5232

\section{Submit your manuscript to a SpringerOpen ${ }^{\circ}$ journal and benefit from:}

- Convenient online submission

- Rigorous peer review

- Immediate publication on acceptance

- Open access: articles freely available online

- High visibility within the field

- Retaining the copyright to your article

Submit your next manuscript at $>$ springeropen.com 